\title{
PENGARUH FAKTOR KARAKTERISTIK PETANI DAN METODE PENYEMPROTAN TERHADAP KADAR KOLINESTERASE
}

\section{AFFECT BETWEEN CHARACTERISTIC FACTORS AND METHOD OF SPRAYING ON CHOLINESTERASE LEVELS}

\author{
Yeviana Dwi Rahmawati \\ CV. Bumi Lestari \\ E-mail: yeviana_dr@yahoo.co.id
}

\begin{abstract}
The farmers efforts to reduce pests are using pesticides. But, there is an adverse effect farmer's health, namely pesticide poisoning. Based on Litbang (2004), the incidence of poisoning were about $80 \%$ in the developing countries. The purpose of this study is to analyze factors which are affected with cholinesterase levels of rice farmers who sprayed pesticides in Sumberejo, Kecamatan Balong, Kabupaten Ponorogo. This study used an observational study design with cross sectional analytic. The sample was all rice farmers who sprayed pesticides in rice plants between 1-7 days before they blood was taken for examination of the enzyme cholinesterase. Total respondents are 40 farmers. The study was in Sumberejo, Kecamatan Balong Kabupaten Ponorogo in July 2013-February 2014. Variables in this study were age, education level, knowledge level, smoking status, used of PPE, work period, the last spraying, direction, time, and duration of spraying, and cholinesterase levels. The primary data was obtained by observation, interview, and spectrophotometer. The technique of data analysis is linier regression test. The results showed that the value of cholinesterase levels is between 5602 U/L-15668 U/L were categorized into moderate and normal. There are no affect characteristic factors (age and work period) on cholinesterase levels. Has affect method of spray (last of spraying) on cholinesterase levels. The conclusion was there is effect between the last of spraying on cholinesterase levels.
\end{abstract}

Keywords: farmers, pesticides, cholinesterase levels

\begin{abstract}
ABSTRAK
Penggunaan pestisida merupakan salah satu upaya petani untuk mengurangi gangguan hama. Di sisi lain, terdapat efek buruk terhadap kesehatan petani, yaitu keracunan pestisida. Berdasarkan data Litbang (2004), pada negara berkembang kejadian keracunan sekitar $80 \%$. Tujuan dari penelitian ini adalah menganalisis faktor yang berhubungan dengan kadar kolinesterase pada petani padi penyemprot pestisida di Desa Sumberejo, Kecamatan Balong, Kabupaten Ponorogo. Penelitian ini menggunakan rancang bangun penelitian observasional analitik dengan pendekatan cross sectional. Sampelnya adalah semua petani padi terakhir melakukan penyemprotan pestisida pada tanaman padi antara $1-7$ hari sebelum diambil darah untuk pemeriksaan enzim kolinesterase, sebanyak 40 responden. Penelitian dilakukan di Desa Sumberejo, Kecamatan Balong, Ponorogo pada bulan Juli 2013-Februari 2014. Variabel pada penelitian ini adalah usia, tingkat pendidikan, tingkat pengetahuan, status perokok, pemakaian APD, lama kerja, terakhir melakukan penyemprotan, arah, waktu, dan lama penyemprotan, serta kadar kolinesterase. Data primer diperoleh dengan melakukan observasi lapangan, wawancara, dan pemeriksaan kadar kolinesterase dengan spectrofotometer. Teknik analisis data dengan uji regresi linier. Hasil pemeriksaan kadar kolinesterase responden menunjukkan nilai antara 5602 U/L-15668 U/L yang dikategorikan menjadi keracunan ringan dan normal. Tidak ada pengaruh faktor karakteristik (usia dan lama kerja) terhadap kadar kolinesterase. Ada pengaruh faktor metode penyemprotan (terakhir penyemprotan) terhadap kadar kolinesterase. Kesimpulannya adalah ada pengaruh antara terakhir penyemprotan terhadap kadar kolinesterase.
\end{abstract}

Kata kunci: petani, pestisida, kadar kolinesterase 


\section{PENDAHULUAN}

Pertanian merupakan salah satu bidang terpenting dalam pemenuhan kebutuhan untuk masyarakat. Hasil dari pertanian tersebut sebagian besar digunakan sebagai bahan pangan pokok masyarakat di Indonesia, misalnya beras, singkong, dan jagung. Hasil lain dari pertanian digunakan sebagai pelengkap bahan pangan pokok, seperti sayur, buah, maupun bahan pelengkap lainnya seperti bumbu untuk memasak.

Salah satu hasil pertanian yang sangat banyak dibutuhkan oleh masyarakat adalah padi. Padi merupakan hasil pertanian yang digunakan oleh sebagian besar masyarakat Indonesia sebagai bahan dasar pangan pokok, antara lain dimasak menjadi nasi, lontong, maupun bubur. Makanan tersebut merupakan makanan yang dianggap wajib sebagai makanan utama.

Selain bermanfaat, pada bidang pertanian juga ada berbagai masalah, diantaranya gangguan dari hama, masalah cuaca yang tidak pasti, serta harga dari bahan yang dibutuhkan pada saat penanaman maupun panen. Namun, masalah yang sangat berpotensi dalam hal keberhasilan panen adalah gangguan dari hama. Penggunaan pestisida merupakan salah satu upaya yang dilakukan para petani untuk mengatasi masalah tersebut.

Jasad pengganggu tersebut antara lain serangga dan kutu yang merusak dan memakan tanaman budi daya seperti gulma di sawah atau perkebunan, gulma air; semua penyakit tanaman budi daya karena jamur pathogen, bakteri dan virus; nematoda seperti tikus, siput, dan burung pemakan kecambah dan biji-bijian dalam jumlah besar. Terbukti pada penelitian yang telah dilakukan di negara maju dan berkembang, bahwa penggunaan pestisida berhasil meningkatkan hasil produksi pertanian dan mengendalikan serangga pembawa penyakit pada manusia. Berdasarkan sejarah, telah tercatat bahwa pestisida telah lama digunakan, yaitu sejak awal adanya peradaban manusia. Contohnya, pada zaman Romawi, sulfur telah mulai digunakan untuk membasmi serangga. Pada abad ke-9, masyarakat China menggunakan garam arsenat untuk membasmi hama serangga di kebun. Pada tahun 1900 senyawa pemberantas gulma dan serangga secara organik yang pertama kali dibuat (Sastroutomo, 1992).

Penggunaan pestisida pada bidang pertanian di Indonesia semakin meningkat dari tahun ke tahun. Hal tersebut karena semakin banyaknya kasus gangguan hama serta kemajuan teknologi. Banyak penelitian mengenai pestisida yang aman untuk tanaman. Petani yang paling banyak menggunakan berbagai pestisida adalah petani sayuran, tanaman pangan, dan tanaman hortikultura buah-buahan (Girsang, 2009). Pestisida yang diperjualbelikan tidak dalam bentuk murni, tetapi harus diproses dahulu sebelum digunakan. Proses ini disebut dengan formulasi. Hasil pestisida yang telah diformulasi ini kemudian dijual dan digunakan oleh para petani. Beberapa jenis formulasi pestisida yang umum digunakan dan dijual antara lain emulsi pekat, serbuk larut air, suspensi, debu, butiran, aerosol, umpan, dan gas.

Sebagian besar cara penggunaan pestisida oleh petani adalah dengan cara penyemprotan. Saat penyemprotan merupakan keadaan petani sangat mungkin terpapar bahan kimia yang terdapat dalam pestisida yang digunakan. Bahaya yang dapat terjadi saat penyemprotan tersebut dapat mengakibatkan gangguan yang dapat mengakibatkan penyakit. Gangguan yang dapat terjadi antara lain adalah gangguan pernapasan, keracunan, gangguan pada darah, dan lain-lain.

Jenis pestisida yang diperjualbelikan ada berbagai macam, tergantung pemanfaatannya. Pestisida yang ada di Indonesia antara lain insektisida $(55,42 \%)$, herbisida $(12,25 \%)$, fungisida $(12,05 \%)$, repelen $(3,61 \%)$, bahan pengawet kayu $(3,61 \%)$, zat pengatur tumbuhan $(3,21 \%)$, rodensia $(2,81 \%)$, bahan perata/perekat $(2,41)$, alansida $(1,4 \%)$, moluskisida $(0,4 \%)$, nematisida $(0,44 \%)$, ajuva $(0,40 \%)$, dan lainnya (1,4\%) (Soemirat, 2003). Berdasarkan data tersebut, diketahui bahwa pestisida yang paling banyak digunakan adalah insektisida.

Organisasi Kesehatan Dunia (WHO) dalam Runia (2008) menyatakan dari 1-5 juta kasus keracunan pestisida pada pekerjaan pertanian, tingkat kematiannya mencapai 220.000 korban jiwa. Berdasarkan Depkes RI dalam Runia (2008), pada negara berkembang, terjadi keracunan sekitar $80 \%$. Menurut data kesehatan Pekanbaru pada tahun 2007, terjadi 446 orang meninggal akibat keracunan pestisida setiap tahunnya. Selain itu, sekitar $30 \%$ mengalami gejala keracunan saat menggunakan pestisida. Hal tersebut terjadi karena petani yang kurang paham mengenai cara penggunaan pestisida yang efektif, serta pemakaian pestisida yang berlebihan (Syarifudin, 2010).

Sebagian besar masyarakat Desa Sumberejo bekerja sebagai petani, yaitu sebanyak 515 orang. Hal ini didukung oleh luas lahan persawahan dengan 
luas $147,26 \mathrm{Ha}^{2}$, sebagian besar lahan ditanami tanaman padi maupun jagung. Untuk meminimalkan masalah tanaman yang ada karena OPT, mereka menggunakan pestisida. Cara penggunaan pestisida sebagian besar adalah dengan cara penyemprotan. Pestisida yang mereka gunakan tersebut selain dapat meminimalkan OPT juga dapat menyebabkan keracunan pestisida pada petani. Cara untuk mengetahui petani tersebut mengalami keracunan pestisida adalah dengan melakukan pemeriksaan kadar kolinesterase dalam darah. Seseorang yang mengalami keracunan pestisida akan memiliki kadar kolinesterase yang rendah. Hal ini karena ada beberapa pestisida yang dapat mengganggu kerja kolinesterase. Beberapa pestisida bersifat anticholinesterase yang dapat menurunkan aktivitas enzim cholinesterase dalam tubuh. Penurunan aktivitas enzim tersebut dapat mengakibatkan terganggunya sistem saraf, keracunan, hingga kematian. Keracunan pestisida pada petani dapat dilihat dengan melihat kadar enzim kolinesterase dalam darah petani. Semakin rendah kadarnya, maka semakin terdeteksi bahwa petani tersebut mengalami keracunan akibat penggunaan pestisida.

Kadar kolinesterase sendiri juga dapat dipengaruhi oleh faktor lain. Menurut Achmadi dalam Purba (2009), faktor tersebut antara lain faktor internal yang terdiri dari usia, status gizi, jenis kelamin, tingkat pendidikan, dan pengetahuan dan faktor eksternal terdiri dari dosis, lama penyemprotan, tindakan penyemprotan terhadap arah angin, waktu penyemprotan, frekuensi penyemprotan, jumlah jenis pestisida yang digunakan, dan penggunaan APD. Achmadi dalam Purba (2009), menyatakan beberapa faktor yang memengaruhi kadar enzim kolinesterase terhadap racun, diantaranya keadaan gizi, status kesehatan, pengobatan, usia, jenis kelamin, suhu, kebiasaan merokok, dan kebiasaan memakai APD. Selain itu, menurut Achmadi dalam Zuraida (2012) menambahkan faktor lain, yaitu lama kerja. Berdasarkan faktor yang memengaruhi terjadinya keracunan pestisida, dapat dikatakan bahwa faktor tersebut dapat memengaruhi kadar enzim kolinesterase dalam darah.

Tujuan dari penelitian ini adalah untuk menganalisis faktor karakteristik petani dan metode penyemprotan yang berpengaruh terhadap kadar kolinesterase darah pada petani padi penyemprot pestisida di Desa Sumberejo, Kecamatan Balong, Kabupaten Ponorogo.

\section{METODE}

Penelitian ini dilakukan dengan menggunakan rancang bangun penelitian observasional analitik dikarenakan bertujuan untuk memperoleh pengaruh faktor karakteristik petani dan metode penyemprotan terhadap kadar kolinesterase pada petani padi pengguna pestisida di Desa Sumberejo, Kecamatan Balong, Kabupaten Ponorogo.

Berdasarkan waktu pengambilan data, penelitian ini menggunakan pendekatan cross sectional, yaitu data yang didapatkan dilakukan pada satu saat atau periode waktu yang sama atau tertentu (Notoatmodjo, 2005).

Populasi pada penelitian ini adalah semua petani padi di Desa Sumberejo, Kecamatan Balong, Kabupaten Ponorogo yang berjumlah 515 orang. Teknik pengambilan sampel dengan menggunakan purposive sampling dengan kriteria inklusi bersedia ikut dalam penelitian dan bersedia diambil darah, serta terakhir penyemprotan tanaman padi antara 1-7 hari sebelum diambil darah untuk pemeriksaan kadar kolinesterase.

Variabel dari penelitian ini antara lain yaitu kadar kolinesterase, faktor karakteristik (usia, tingkat pendidikan, tingkat pengetahuan, status perokok, dan lama kerja), dan faktor metode penyemprotan (pemakaian APD, terakhir penyemprotan, waktu penyemprotan, dan lama penyemprotan). Data yang dikumpulkan berupa data primer dan sekunder. Data primer diperoleh dengan menggunakan lembar observasi, pedoman wawancara, dan pemeriksaan kadar kolinesterase.

Teknik analisis data dilakukan dengan 2 cara, yaitu statistik deskriptif dan analisis regresi linier. Statistik deskriptif digunakan untuk melihat gambaran atau distribusi dari setiap variabel dependen dan independen. Analisis regresi linier digunakan untuk melihat pengaruh variabel independen terhadap dependen. Syarat analisis regresi linier adalah distribusi data normal, variabel dependen berskala data minimal interval, dan variabel independen berskala data minimal nominal. Oleh karena itu, setiap variabel terlebih dahulu harus diuji normalitas dengan menggunakan uji Kolmogorov Smirnov.

\section{HASIL}

\section{Distribusi Karakteristik Petani}

Hasil penelitian untuk usia responden menunjukkan rentang usia antara 29 sampai 
70 tahun. Distribusi usia responden pada penelitian ini dikelompokkan berdasarkan setiap usia yang ada. Hasil analisis usia responden diketahui bahwa responden terbanyak adalah pada usia 45 dan 50 tahun sebanyak $10 \%$ responden.

Hasil penelitian untuk tingkat pendidikan responden terdiri mulai dari tidak sekolah sampai SMA. Berdasarkan PP No. 47 tahun 2008 tentang wajib belajar, yaitu minimal sampai pada tingkat lulus SMP. Distribusi tingkat pendidikan pada penelitian ini dibagi menjadi 2, yaitu tidak lulus $\mathrm{SMP} /$ setara dan lulus SMP/setara. Hasil analisis tingkat pendidikan responden diketahui bahwa responden terbanyak adalah pada tingkat pendidikan lulus SD yaitu sebanyak $57,5 \%$ responden.

Pengetahuan responden terhadap penanganan pestisida diketahui dengan cara melakukan wawancara berupa kuesioner maupun pertanyaan langsung kepada responden. Pertanyaan yang diberikan kepada responden untuk mengetahui pemahaman yang berhubungan dengan bahaya pestisida, cara penyimpanan pestisida, pertolongan pertama bila terjadi keracunan, cara membersihkan peralatan, dan alat pelindung diri yang harus digunakan saat penyemprotan pestisida. Tingkat pengetahuan memiliki nilai minimal 0 dan nilai maksimal 29. Tingkat pengetahuan pada penelitian ini dibagi menjadi 2 kategori, yaitu kurang jika nilai responden antara $0-14$, dan baik jika nilai responden lebih dari 14. Hasil analisis tingkat pengetahuan diketahui bahwa responden terbanyak adalah tingkat pengetahuan kategori kurang (0-14) yaitu sebanyak $72,5 \%$ responden.

Hasil penelitian untuk status perokok dikelompokkan menjadi perokok aktif dan pasif. Dikatakan perokok aktif adalah apabila setiap hari responden merokok minimal sehari menghabiskan satu batang rokok. Hasil analisis kebiasaan merokok responden diketahui bahwa responden terbanyak adalah perokok aktif yaitu sebanyak $57,5 \%$ responden.

Hasil analisis lama kerja responden sebagai petani penyemprot padi diketahui bahwa responden terbanyak adalah masa kerja 20 dan 25 tahun yaitu sebanyak $20 \%$ responden.

\section{Distribusi Metode Penyemprotan}

APD yang harus digunakan saat penyemprotan adalah masker, pakaian lengan panjang, dan sarung tangan. Pemakaian APD dikatakan lengkap jika memakai APD lebih dari 1, sedangkan jika tidak memakai APD atau hanya memakai 1 jenis APD saat penyemprotan maka termasuk tidak lengkap. Hasil analisis pemakaian APD saat penyemprotan pestisida diketahui bahwa responden terbanyak adalah pemakaian APD tidak lengkap yaitu sebanyak $77,5 \%$ responden. APD yang paling banyak dipakai responden adalah masker. Namun, masker yang mereka pakai adalah baju yang dililit untuk menutupi mulut dan hidung mereka. Alasan responden tidak menggunakan APD adalah karena merasa terganggu dan tidak dapat bernapas saat memakai penutup mulut dan hidung.

Hasil analisis responden terakhir melakukan penyemprotan padi diketahui bahwa responden terbanyak adalah terakhir penyemprotan 2 hari yaitu sebanyak $30 \%$ responden.

Cara penyemprotan pestisida terdapat 2 jenis berdasarkan arah penyemprotannya, yaitu searah dengan arah angin dan tidak searah arah angin. Hasil analisis arah semprot terhadap arah angin saat penyemprotan diketahui bahwa responden terbanyak adalah penyemprotan searah dengan arah angin saat penyemprotan yaitu sebanyak $77,5 \%$ responden. Hasil analisis waktu penyemprotan diketahui bahwa responden terbanyak adalah melakukan penyemprotan pada siang/sore hari yaitu sebanyak $97,5 \%$ responden. Hasil analisis lama penyemprotan diketahui bahwa responden terbanyak adalah melakukan penyemprotan selama 2 jam yaitu sebanyak $27,5 \%$ responden.

\section{Distribusi Kadar Kolinesterase}

Berdasarkan pemeriksaan kadar kolinesterase dengan menggunakan spectrophotometer, terdapat 2 kelompok kadar kolinesterase yaitu kelompok normal dan abnormal. Kelompok keracunan berat berada pada kadar kolinesterase $<5100 \mathrm{U} / \mathrm{L}$, keracunan ringan berada pada kadar antara 5100 U/L sampai $11700 \mathrm{U} / \mathrm{L}$, sedangkan normal apabila $>11700 \mathrm{U} / \mathrm{L}$. Hasil analisis kadar kolinesterase menunjukkan bahwa setiap responden memiliki kadar kolinesterase yang berbeda dengan nilai kadar kolinesterase terendah adalah $5602 \mathrm{U} / \mathrm{L}$ dan tertinggi adalah $15668 \mathrm{U} / \mathrm{L}$. Terdapat 36 orang (90\%) termasuk kelompok kadar kolinesterase keracunan ringan.

\section{Analisis Pengaruh Faktor Karakteristik Petani terhadap Kadar Kolinesterase}

Berdasarkan hasil uji normalitas, didapatkan bahwa hanya faktor usia dan lama kerja yang 
memiliki distribusi data normal. Hal ini berarti hanya faktor tersebut yang dapat dilakukan analisis regresi dengan menggunakan regresi linier untuk melihat pengaruh terhadap kadar kolinesterase. Sedangkan faktor yang tidak berdistribusi normal dapat dilakukan analisis hubungan dengan menggunakan uji chi-square maupun Fisher's.

Berdasarkan hasil analisis dengan menggunakan regresi linier, didapatkan $\mathrm{R}$ sebesar 0,194 yang berarti ada hubungan tetapi tidak bermakna antara usia dan lama kerja terhadap kadar kolinesterase. Faktor usia didapatkan nilai signifikansi 0,941 yang berarti tidak ada pengaruh antara usia dengan kadar kolinesterase. Faktor lama kerja didapatkan nilai signifikansi 0,552 yang berarti juga tidak ada pengaruh antara lama kerja terhadap kadar kolinesterase. Hasil analisis regresi didapatkan model:

$y=8121,612+4,681$ (usia) $+40,350$ (lama kerja)

Selain faktor usia dan lama kerja, faktor karakteristik lainnya yaitu tingkat pendidikan, tingkat pengetahuan, dan status perokok tidak memiliki distribusi normal sehingga tidak dapat dilakukan analisis regresi. Faktor lain yang tidak memiliki distribusi tidak normal kemudian dilakukan uji hubungan.

Responden dengan tingkat pendidikan lulus SD sebanyak 20 orang (27\%) memiliki hasil pemeriksaan kadar kolinesterase keracunan ringan. Hasil uji Chi-square diperoleh nilai $\mathrm{p}=0,557$, sehingga dapat diketahui bahwa tidak ada hubungan antara tingkat pendidikan dengan kadar kolinesterase pada petani penyemprot padi di Desa Sumberejo, Kecamatan Balong, Kabupaten Ponorogo.

Responden dengan tingkat pengetahuan kurang (0-14) sebanyak 25 orang $(86,2 \%)$ memiliki hasil pemeriksaan kadar kolinesterase keracunan ringan. Hasil uji Fisher's diperoleh nilai $\mathrm{p}=0,560$, sehingga dapat diketahui bahwa tidak ada hubungan antara tingkat pengetahuan dengan kadar kolinesterase pada petani penyemprot padi di Desa Sumberejo, Kecamatan Balong, Kabupaten Ponorogo.

Responden dengan status perokok aktif sebanyak 21 orang $(91,3)$ memiliki hasil pemeriksaan kadar kolinesterase keracunan ringan. Hasil uji Fisher's diperoleh nilai $\mathrm{p}=1,000$, sehingga dapat diketahui bahwa tidak ada hubungan antara status perokok dengan kadar kolinesterase pada petani penyemprot padi di Desa Sumberejo, Kecamatan Balong, Kabupaten Ponorogo.

\section{Analisis Pengaruh Faktor Metode Penyemprotan terhadap Kadar Kolinesterase}

Berdasarkan hasil uji normalitas, didapatkan bahwa hanya faktor terakhir penyemprotan dan lama penyemprotan yang memiliki distribusi data normal. Hal ini berarti hanya faktor tersebut yang dapat dilakukan analisis regresi dengan menggunakan regresi linier untuk melihat pengaruh terhadap kadar kolinesterase. Sedangkan faktor yang tidak berdistribusi normal dapat dilakukan analisis hubungan dengan menggunakan uji chi-square maupun Fisher's.

Berdasarkan hasil analisis dengan menggunakan regresi linier, didapatkan $\mathrm{R}$ sebesar 0,821 yang berarti ada hubungan bermakna antara terakhir penyemprotan dan lama penyemprotan terhadap kadar kolinesterase. Faktor terakhir penyemprotan didapatkan nilai signifikansi 0,000 yang berarti ada pengaruh antara terakhir penyemprotan dengan kadar kolinesterase. Faktor lama penyemprotan didapatkan nilai signifikansi 0,955 yang berarti tidak ada pengaruh antara lama penyemprotan terhadap kadar kolinesterase. Hasil analisis regresi didapatkan model:
$y=5635,960+1115,710$ (terakhir penyemprotan) - 12,953 (lama penyemprotan)

Selain faktor terakhir penyemprotan dan lama penyemprotan, faktor metode penyemprotan lainnya yaitu pemakaian APD, arah penyemprotan, dan waktu penyemprotan tidak memiliki distribusi normal sehingga tidak dapat dilakukan analisis regresi. Faktor lain yang tidak memiliki distribusi tidak normal kemudian dilakukan uji hubungan. Pemakaian APD pada saat penyemprotan dapat memengaruhi jumlah partikel pestisida masuk ke dalam tubuh penyemprot. Alat pelindung diri yang harus digunakan pada saat menyemprot antara lain masker, baju lengan panjang, dan sarung tangan. Semakin lengkap APD yang digunakan saat penyemprotan, maka kemungkinan kadar kolinesterase yang tidak normal semakin kecil. Responden dengan pemakaian APD tidak lengkap sebanyak 27 orang memiliki hasil pemeriksaan kadar kolinesterase keracunan ringan. Hasil uji Fisher's diperoleh nilai $p=0,557$, sehingga dapat diketahui bahwa tidak ada hubungan antara pemakaian APD dengan kadar kolinesterase pada petani penyemprot padi di Desa Sumberejo, Kecamatan Balong, Kabupaten Ponorogo. 
Responden dengan arah semprot yang tidak searah dengan angin sebanyak 8 orang $(88,9 \%)$ memiliki hasil pemeriksaan kadar kolinesterase keracunan ringan. Hasil uji Fisher's diperoleh nilai $\mathrm{p}=1,000$, sehingga dapat diketahui bahwa tidak ada hubungan antara arah penyemprotan dengan kadar kolinesterase pada petani penyemprot padi di Desa Sumberejo, Kecamatan Balong, Kabupaten Ponorogo.

Responden dengan waktu penyemprotan pada pagi hari sebanyak 1 orang memiliki hasil pemeriksaan kadar kolinesterase keracunan ringan. Hasil uji Fisher's diperoleh nilai $\mathrm{p}=1,000$, sehingga dapat diketahui bahwa tidak ada hubungan antara waktu penyemprotan dengan kadar kolinesterase pada petani penyemprot padi di Desa Sumberejo, Kecamatan Balong, Kabupaten Ponorogo.

\section{PEMBAHASAN}

\section{Distribusi Karakteristik Petani}

Faktor internal usia terdiri antara usia 29 sampai 70 tahun. Hal ini menunjukkan bahwa pekerjaan penyemprotan sudah dimulai pada usia muda sampai usia tua. Hasil penelitian usia 45 dan 50 tahun memiliki persentase terbanyak, yaitu $10 \%$. Faktor usia pada petani penyemprot pestisida di Desa Sumberejo, Kecamatan Balong, Ponorogo, ini dapat berdampak pada kadar kolinesterase mereka. Hal ini karena usia tertua adalah usia 70 tahun. Achmadi (2005) menyatakan bahwa bertambahnya usia seseorang, maka kadar rata-rata kolinesterase akan semakin rendah. Keadaan tersebut dapat dikarenakan semakin tua usia seseorang maka kemungkinan fungsi organ dalam menurun, misalnya gangguan hati atau ginjal, yang dapat memengaruhi nilai dari kadar kolinesterase dalam darah. Organ hati dan ginjal mempunyai fungsi fisiologis sebagai penetralisir racun dan bahan kimia yang masuk ke dalam tubuh, apabila terdapat penurunan fungsi dari organ tersebut maka dapat menyebabkan penimbunan racun dan bahan kimia yang berbahaya dalam tubuh yang dapat bersifat kronis atau akut.

Faktor tingkat pendidikan dikelompokkan pada tidak lulus SD, lulus SD, lulus SMP, dan lulus SMA didapatkan bahwa tingkat pendidikan lulus SD adalah kelompok terbanyak. Hal ini menunjukkan bahwa tingkat pendidikan petani penyemprot pestisida masih tergolong rendah. Pendidikan yang lebih tinggi diharapkan pengetahuan tentang pestisida dan bahayanya juga lebih baik dibandingkan dengan tingkat pendidikan yang rendah (Achmadi, 2005).
Pendidikan formal seseorang akan memberikan tambahan pengetahuan, sehingga pada pendidikan yang lebih tinggi diharapkan dapat mengetahui apa saja bahaya yang mungkin dapat terjadi akibat dari pemakaian pestisida dan mengetahui cara preventif dalam pemakaian pestisida.

Faktor tingkat pengetahuan menunjukkan bahwa pengetahuan para petani masih banyak yang kurang. Banyak petani yang tidak mengetahui mengenai bahaya pestisida, penanganan dan penyimpanan pestisida, dan cara pencegahan agar tidak terjadi keracunan pestisida. Selain itu, banyak juga petani yang tidak mengetahui cara pertolongan pertama apabila terjadi keracunan pestisida. Petani banyak yang tidak peduli mengenai penanganan dan pemakaian pestisida yang benar. Apabila hal tersebut dibiarkan tanpa ada penyuluhan, maka para petani pada waktu yang akan lama dapat mengalami masalah keracunan kronis. Achmadi (2005) menyatakan bahwa semakin baik pengetahuan seseorang maka dorongan untuk melakukan tindakan secara tepat sesuai aturan kesehatan sehingga risiko terjadinya keracunan pestisida dapat dicegah atau dikurangi.

Status perokok menunjukkan bahwa masih banyak petani sebagai perokok aktif. Achmadi dalam purba (2009) menyatakan bahwa terdapat senyawa dalam rokok, diantaranya nikotin, yang memiliki pengaruh serupa dengan pengaruh antikolinesterase terhadap serabut otot sehingga mampu menginaktifkan kolinesterase yang menyebabkan dalam keadaan sinaps, tidak akan menghidrolisis acetylcholine. Sehingga merokok dapat memperparah kejadian menurunnya kolinesterase.

Lama kerja menunjukkan bahwa banyak petani yang sudah lama bekerja sebagai petani penyemprot pestisida. Lama kerja terbanyak adalah masa kerja 20 dan 25 tahun. Mereka bekerja sebagai petani penyemprot pestisida kebanyakan mulai usia remaja. Hal tersebut dapat terlihat dari lama mereka kerja dengan usia. Semakin lama bekerja sebagai petani maka semakin sering kontak dengan pestisida sehingga risiko terjadinya keracunan pestisida semakin tinggi (Achmadi, 2005).

\section{Distribusi Metode Penyemprotan}

Pestisida masuk ke dalam tubuh dapat melalui berbagai cara, antara lain melalui pernapasan atau penetrasi kulit. Oleh karena itu cara yang paling baik untuk mencegah terjadinya keracunan adalah memberikan perlindungan pada bagian tersebut 
(Achmadi, 2005). Pemakaian APD menunjukkan masih banyak petani yang kurang memperhatikan keselamatan pada saat menyemprot. Hal ini terlihat dengan tidak lengkapnya APD yang mereka gunakan saat penyemprotan, bahkan ada beberapa petani yang tidak menggunakan APD. Mereka tidak memakai APD karena dianggap mengganggu saat mereka bekerja. APD yang banyak digunakan adalah masker penutup hidung dan mulut. Namun, masker yang mereka gunakan adalah kain baju yang sudah tidak terpakai. Masker tersebut digunakan karena dianggap sudah aman. Pemakaian APD yang seharusnya adalah memakai masker, baju lengan panjang, sarung tangan yang terbuat dari bahan karet, sepatu dengan bagian atas yang panjang sampai di bawah lutut yang terbuat dari bahan yang kedap air, tahan terhadap asam, basa atau bahan korosif lainnya.

Faktor waktu terakhir penyemprotan pada penelitian ini menunjukkan bahwa banyak petani yang melakukan penyemprotan terakhir kali 2 hari sebelum dilakukan pemeriksaan kadar kolinesterase. Kadar kolinesterase dapat kembali normal secara bertahap semakin lama jarak setelah penyemprotan. Simbolon dalam Rustia (2010) menyatakan bahwa waktu kontak terakhir dengan pestisida yang lama akan memberikan pengaruh yang besar terhadap penurunan aktivitas kolinesterase. Hasil penelitian lainnya, yaitu Suryamah dalam Rustia (2010) juga menyatakan bahwa petani yang melakukan penyemprotan terakhir $\leq 2$ minggu memiliki risiko sebesar 5,8 kali mengalami keracunan dibandingkan dengan petani yang melakukan penyemprotan terakhir $>2$ minggu. Pestisida dapat memberikan efek secara langsung terhadap kadar kolinesterase seseorang. Namun, tidak semua jenis pestisida efeknya dapat terlihat berdasarkan kadar kolinesterasenya setelah melakukan penyemprotan.

Faktor arah penyemprotan menunjukkan bahwa sebagian besar petani melakukan penyemprotan searah dengan angin. Achmadi (2005) menyatakan bahwa arah angin harus diperhatikan oleh penyemprot saat menyemprot, penyemprotan yang baik adalah bila searah dengan arah angin. Apabila penyemprotan tidak searah dengan arah angin, maka pestisida tersebut dapat mengenai tubuh atau terhirup oleh penyemprot sehingga dapat menyebabkan keracunan pestisida. Hal ini dikarenakan arah angin tersebut mengarahkan pestisida yang disemprotkan. Oleh karena itu, sebaiknya penyemprotan dilakukan dengan searah dengan arah angin.
Faktor waktu penyemprotan menunjukkan bahwa penyemprotan dilakukan pada pagi hari. Achmadi (2005) menyatakan bahwa pagi hari merupakan waktu yang paling baik untuk melakukan penyemprotan, karena suhu lingkungan tidak terlalu panas dibandingkan dengan siang hari yang dapat menyebabkan produksi keringat lebih banyak. Sehingga waktu penyemprotan semakin siang akan mudah terjadi keracunan pestisida terutama penyerapan melalui kulit.

Faktor lama penyemprotan pada penelitian ini menunjukkan bahwa banyak petani yang melakukan penyemprotan selama 2 jam. Hal ini karena luas sawah yang mereka semprot tidak terlalu besar. Semakin lama melakukan penyemprotan, maka pestisida yang terpapar akan semakin banyak. Hal tersebut dapat memengaruhi tubuh terkena atau masuknya pestisida sehingga dapat menyebabkan terjadinya keracunan.

\section{Distribusi Kadar Kolinesterase}

Pemeriksaan kadar kolinesterase pada penelitian ini menggunakan metode spektrofotometer. Pemeriksaan kadar kolinesterase dapat digunakan sebagai acuan apakah seseorang mengalami keracunan pestisida atau tidak dengan melihat nilai dari kadar kolinesterasenya. Kadar kolinesterase $<5100 \mathrm{U} / \mathrm{L}$ dikategorikan kadar kolinesterase darah terganggu (keracunan berat), antara 5100-11700 U/L dikategorikan kadar kolinesterase darah berpotensi keracunan (keracunan ringan), sedangkan $>11700$ $\mathrm{U} / \mathrm{L}$ dikategorikan kadar kolinesterase darah normal. Hasil pemeriksaan kadar kolinesterase darah pada petani padi penyemprot pestisida di Desa Sumberejo, Kecamatan Balong, Ponorogo didapatkan nilai terendah $5602 \mathrm{U} / \mathrm{L}$ dan nilai tertinggi 15668 U/L. Sebagian besar responden memiliki kadar kolinesterase keracunan ringan. Tingkat kadar kolinesterase tersebut dapat dipengaruhi oleh beberapa faktor.

\section{Analisis Pengaruh Faktor Karakteristik Petani terhadap Kadar Kolinesterase}

Hasil analisis regresi linier berganda didapatkan bahwa tidak ada pengaruh antara faktor usia dan lama kerja terhadap kadar kolinesterase. Namun terdapat hubungan dengan kuat hubungan sangat rendah antara faktor usia dan lama kerja dengan kadar kolinesterase. Faktor usia tidak ada pengaruh terhadap kadar kolinesterase dapat dikarenakan 
faktor lain yang tidak diteliti, yaitu status gizi. Faktor lama kerja tidak ada pengaruh terhadap kadar kolinesterase dapat dikarenakan selama faktor lain yaitu pestisida yang digunakan tidak terlalu beracun sehingga kadar kolinesterase orang tersebut tidak dipengaruhi sudah berapa lama mereka bekerja sebagai penyemprot pestisida.

Faktor lain yang tidak dilakukan uji regresi linier, kemudian dilakukan uji hubungan dengan menggunakan uji chi-square atau Fisher's. Hubungan faktor tingkat pendidikan dengan kadar kolinesterase didapatkan tidak ada hubungan. Uji hubungan ini dengan menggunakan chi-square. Hasil tersebut sesuai dengan penelitian Zuraida (2012) yang menyatakan bahwa tidak ada hubungan bermakna antara tingkat pendidikan rendah dan tinggi dengan kejadian keracunan pestisida. Namun hal ini tidak sesuai dengan Achmadi (2005), dikarenakan orang yang memiliki pendidikan tinggi tidak selalu memiliki pengetahuan yang baik. Selain itu, pengetahuan mengenai penanganan pestisida yang baik dan aman dapat diperoleh dari pendidikan non-formal, khususnya mengenai keamanan dan kesehatan dalam pemakaian pestisida. Sehingga pengetahuan tidak hanya didapatkan dari pendidikan formal saja.

Hubungan faktor tingkat pengetahuan dengan kadar kolinesterase didapatkan tidak ada hubungan. Uji hubungan ini dengan menggunakan uji Fisher's. Hasil tersebut sesuai dengan penelitian Afriyanto (2008) dan Zuraida (2012) yang menyatakan bahwa tidak ada hubungan bermakna antara tingkat pengetahuan dengan kejadian keracunan pestisida. Namun, hal ini tidak sesuai dengan Achmadi (2005). Pengetahuan yang baik belum tentu memiliki perilaku dan sikap yang baik dan aman. Sebagian besar petani mengetahui APD yang harus digunakan saat melakukan penyemprotan, namun banyak dari mereka yang tidak menggunakannya. Tanda keracunan yang terjadi pun mereka anggap biasa dan dibiarkan sembuh dengan sendirinya. Oleh karena itu, pada penelitian ini tidak ada hubungan antara tingkat pengetahuan dengan kadar kolinesterase.

Hubungan faktor status perokok dengan kadar kolinesterase didapatkan tidak ada hubungan. Uji hubungan ini dengan menggunakan uji Fisher's. Hasil tersebut tidak sesuai dengan Achmadi dalam Purba (2009). Hal ini dapat dikarenakan petani tersebut jarang merokok saat penyemprotan. Sehingga kecil kemungkinan terjadi penurunan pestisida karena proses pertahanan tubuh yang dapat menurun efek dari rokok yang dapat menyebabkan menurunnya kadar kolinesterase.

\section{Analisis Pengaruh Faktor Metode Peneymprotan Terhadap Kadar Kolinesterase}

Hasil analisis regresi linier berganda didapatkan bahwa ada hubungan antara faktor terakhir dan lama penyemprotan dengan kadar kolinesterase dengan kuat hubungan sangat kuat. Faktor terakhir penyemprotan ada pengaruh penyemprotan terhadap kadar kolinesterase. Hal ini sesuai dengan hasil penelitian Simbolon dan Suryamah dalam Rustia (2010). Pestisida dalam tubuh dapat bertahan selama beberapa hari sampai 2 minggu setelah penyemprotan. Akibat dari masuknya pestisida ke dalam tubuh, akan menyebabkan menurunnya kadar kolinesterase dalam darah. Kadar kolinesterase dapat kembali normal secara bertahap semakin lama jarak setelah penyemprotan. Hasil pada penelitian ini tidak ada hubungan dapat dikarenakan faktor lain, yaitu jenis pestisida yang digunakan tidak bersifat terlalu beracun atau dosis yang digunakan tidak banyak karena luas lahan penyemprotan tidak terlalu luas. Faktor lama penyemprotan didapatkan tidak ada pengaruh terhadap kadar kolinesterase. Hasil ini tidak sesuai dengan Achmadi (2005). Hal ini dapat dikarenakan luas lahan yang disemprot tidak terlalu luas. Sehingga waktu pajanan dengan pestisida tidak terlalu lama. Selain itu, dapat dikarenakan faktor lain yang tidak diteliti yaitu jenis dan jumlah dosis penelitian.

Faktor lain yang tidak dilakukan uji regresi linier, kemudian dilakukan uji hubungan menggunakan uji chi-square atau Fisher's. Hubungan faktor pemakaian APD dengan kadar kolinesterase didapatkan tidak ada hubungan. Uji hubungan ini dengan menggunakan Fisher's. Hasil tersebut sesuai dengan penelitian Afriyanto (2008) dan Zuraida (2012) yang menyatakan bahwa tidak ada hubungan bermakna antara tingkat pengetahuan dengan kejadian keracunan pestisida. Pemakaian APD pada penelitian ini tidak memperhatikan mengenai cara mereka memakai APD yang benar. Masker yang mereka gunakan adalah kain baju yang sudah tidak terpakai. Hal tersebut tidak sesuai dengan standar masker yang seharusnya mereka gunakan. Masker yang seharusnya digunakan adalah disposable face mask. Selain itu, dapat dikarenakan pemakaian APD yang tidak konsisten selama penyemprotan. Mereka tahu dan memiliki APD yang 
harus digunakan. Tetapi apabila dirasa mengganggu, mereka tidak memakai APD tersebut.

Hubungan faktor arah penyemprotan dengan kadar kolinesterase didapatkan tidak ada hubungan. Uji hubungan ini dengan menggunakan Fisher's. Hasil ini tidak sesuai dengan Achmadi (2005). Hasil penelitian Afriyanto (2008) menyatakan ada hubungan antara arah menyemprot terhadap arah angin dengan kejadian keracunan pestisida. Hal ini dapat dikarenakan faktor lain seperti pemakaian APD. Saat penyemprotan, kebanyakan petani hanya menggunakan kaos tanpa pelindung badan lainnya. Selain itu, kaos yang mereka gunakan tidak berlengan panjang. Meskipun penyemprotan dilakukan dengan searah angin, kemungkinan terpapar pestisida tetap ada dari penyemprot pestisida lain yang ada di sekitar lahan penyemprotannya.

Hubungan faktor waktu penyemprotan dengan kadar kolinesterase didapatkan tidak ada hubungan. Uji hubungan ini dengan menggunakan Fisher's. Hal ini dikarenakan hampir seluruh responden melakukan penyemprotan pada pagi hari. Menurut Achmadi (2005), waktu yang tepat untuk menyemprot adalah pada pagi hari.

\section{SIMPULAN}

Faktor karakteristik responden di Desa Sumberejo, Kecamatan Balong Kabupaten Ponorogo tahun 2013 terbanyak pada usia kelompok usia 45 dan 50 tahun, tingkat pendidikan lulus SD, pengetahuan kurang, status perokok aktif, dan lama kerja 20 dan 25 tahun.

Faktor metode penyemprotan responden di Desa Sumberejo, Kecamatan Balong, Kabupaten Ponorogo tahun 2013 terbanyak pada pemakaian APD tidak lengkap, terakhir penyemprotan 2 hari, arah penyemprotan searah angin, waktu penyemprotan pagi dari, dan lama penyemprotan 2 jam.

Hasil pemeriksaan kadar kolinesterase responden di Desa Sumberejo, Kecamatan Balong, Kabupaten Ponorogo tahun 2013 terdiri dari keracunan ringan dengan nilai $5100 \mathrm{U} / \mathrm{L}-11700 \mathrm{U} / \mathrm{L}$ sebanyak 36 orang ( $90 \%$ ) sedangkan normal dengan nilai $>11700 \mathrm{U} / \mathrm{L}$ sebanyak 4 orang $(10 \%)$.

Tidak ada pengaruh antara faktor karakteristik (usia dan lama kerja) terhadap kadar kolinesterase dengan kuat hubungan sangat lemah $(\mathrm{R}=0,194)$. Faktor karakteristik lain (tingkat pendidikan, tingkat pengetahuan, dan status perokok) tidak ada hubungan dan pengaruh terhadap kadar kolinesterase di Desa Sumberejo, Kecamatan Balong, Kabupaten Ponorogo tahun 2013.

Ada pengaruh antara faktor metode penyemprotan (terakhir penyemprotan) terhadap kadar kolinesterase $(\alpha=0,000)$. Tidak ada pengaruh antara faktor lama penyemprotan terhadap kadar kolinesterase. Kuat hubungan terakhir penyemprotan dan lama penyemprotan memiliki kuat hubungan sangat kuat $(\mathrm{R}=0,821)$. Faktor metode penyemprotan lain (pemakaian APD, arah penyemprotan, dan waktu penyemprotan) tidak ada hubungan dan pengaruh terhadap kadar kolinesterase di Desa Sumberejo, Kecamatan Balong, Kabupaten Ponorogo tahun 2013.

\section{DAFTAR PUSTAKA}

Girsang, Warlinson. 2013. Dampak Negatif Penggunaan Pestisida. http://usitani. wordpress. com/2009/02/26/dampak-negatif-penggunaanpestisida/ (sitasi 5 Juli 2013).

Notoadmodjo, Soekidjo. 2005. Metodologi Penelitian Kesehatan. Jakarta: PT. Rineka Cipta.

Purba, Imelda Gernauli. 2009. Analisis Faktor-faktor yang Berhubungan dengan Kadar Kolinesterase pada Perempuan Usia Subur di Daerah Pertanian. Tesis. Semarang: Universitas Diponegoro.

Runia, Yodenca Assti. 2008. Faktor-faktor yang Berhubungan dengan Keracunan Pestisida Organofosfat, Karbamat dan Kejadian Anemia pada Petani Hortikultura di Desa Tejosari Kecamatan Ngablak Kabupaten Magelang. Tesis. Semarang: Universitas Diponegoro.

Rustia, Hana Nika. dkk. 2010. Lama Pajanan Organofosfat terhadap Penurunan Aktivitas Enzim Kolinesterase dalam Darah Petani Sayuran. Makara, Kesehatan, Vol. 14, No. 2: 95-101.

Sastroutomo, Soetikno S. 1992. Pestisida DasarDasar dan Dampak Penggunaannya. Jakarta: Gramedia Pustaka Utama.

Soemirat, J. 2003. Toksikologi Lingkungan. Yogyakarta: Gajah Mada University Press.

Syarifudin, Arief. 2013. Pendahuluan. http:// pestisida-riefarmasi.blogspot.com/ (sitasi 5 Juli 2013).

Zuraida. 2012. Faktor yang Berhubungan dengan Tingkat Keracunan Pestisida pada Petani di Desa Srimahi Tambun Utara, Bekasi Tahun 2011. Skripsi. Depok: Universitas Indonesia. 